\title{
THE SCAFFOLDING CAUSALITIC-THINKING APPROACH TO INCREASE THE PROBLEM-SOLVING ABILITY OF STUDENTS ON FLUIDS
}

\author{
Joni Rokhmat ${ }^{1}$, Marzuki ${ }^{2}$, Hikmawati ${ }^{3}$, Ni Nyoman Sri Putu Verawati ${ }^{4}$ \\ joni.fkip@unram.ac.id ${ }^{1}$ \\ Program of Physics Education, Universitas Mataram, Indonesia ${ }^{1,3,4}$ \\ Department of Physics, Universitas Mataram, Indonesia ${ }^{2}$
}

\begin{abstract}
Scaffolding causalitic-thinking is a specific approach to facilitate students in analyzing cause and effect of a phenomenon and in establishing reason where some assistance stages are given. Patterns of the assistance include informing number of causes, effects, or both, some example of causes, effects, or both (causes and effects), or some of its arguments. This scaffolding orientation was to facilitate students to increase their Problem-solving Ability (PSA) and had been implemented on fluid in Senior High School (SHS). The PSA includes understanding, selecting, differentiating, determining, applying and identifying. This research aimed to investigate an impact of the approach on the PSA that is related to gender and Junior High School (JHS) origin of the students, Sekolah Menengah Pertama (SMP) and other (non-SMP). This research used mixed method of embedded experimental two-phase design and with sample of 33 students, 22 females and 11 males, for control class and 32 students, 17 females and 15 males, for experiment class. Total score of the six abilities were tested with ANAVA two factor design. The results, among 6 pairs of $F_{\text {counted }}$ and $F_{\text {table }}$ showed $67 \%$ that indicate $F_{\text {counted }}>F_{\text {table. }}$. The results indicated that the approach affects PSA of students and the effect was different between male and female, also the interaction between the origin of JHS students and the approach. Next, patterns of the scaffolding approach are considerably used as reference when arranging worksheet to conduct Physics or other discipline learning with this approach in practice or further research.
\end{abstract}

Keywords: Scaffolding causalitic-thinking; Problem-solving; Gender; Original junior-highschool; Fluids.

\section{INTRODUCTION}

A number of researchers have improved the quality of Physics learning through research activities. As examples, Baser (2006) uses conflict-cognitive learning, Yürük (2007) implements process of meta-conceptual, awareness, monitoring, and conceptual evaluation, Hake (2007) develops learning based on Interactive engagement, Escudero (2009) develops theorem-in-action learning, and Dykstra (2009) uses demonstration of three accelerated movements. Next, Dori (2004) uses Technology Enabled Active Learning (TEAL)-studio format, Obaidat (2009) uses power point presentation and experimental demonstration, Hung (2006) uses causal reasoning, Rasagama (2011) develops Physics Lecturing Program (PLP) to increase ability of analyzing and creating, and Rokhmat (2013, 2015, and 2017) uses causalitic (causality and analytic) thinking approach to increase Problem-solving ability (PSA) of students.

Rokhmat (2013, 2015, 2017) has implemented causalitic learning approach to investigate its impact to PSA on seven subjects, kinematics, Newton's law about movement, work and energy, linear momentum, gravity, rigid body equilibrium, and 
thermodynamics. He finds that the PSA increased significantly. This approach is aimed to facilitate pre-service teachers in developing their ability in causalitic-thinking. Since 2016, he has been developing instrument of Physics learning with Causalitic-thinking Approach (CTA) to increase PSA of Senior High School (SHS) students and has implemented it on fluid, heat, electric, and rigid body equilibrium. To optimize effectiveness of the approach, he uses scaffolding form of the approach. Rokhmat (2013, 2015, 2017) introduces nine patterns of this approach one of them is standard while the others are scaffolding forms.

The relation between PSA achievements (in fluids learning with CTA) and gender (male and female) and between the PSA achievements and the origin JHS of the students (SMP and non-SMP): Rokhmat (2013, 2015, and 2017) introduced that the CTA is closely related to phenomenon with more than one possible correct answer which is also concerned to divergent thinking (Meyer, 2015). The phenomenon in this sort is linked very closely to creative thinking that supports academic achievement (Anwar, 2012). Next, Piaw (2013) revealed that male students are more creative than female ones. In view of origin JHS, in general, the SMP is more favorite than non-SMP and so students originate from SMP are predicted indicate higher PSA than those of non-SMP.

As described above, this paper will focus on discussing the impact of the scaffolding approach in increasing PSA of SHS students on fluid. The increase is related to gender and origin of Junior High school (JHS) students. Finally, this paper is directed to answer two questions: 1) How the CTA in scaffolding patterns affected PSA with respect to gender and the origin of JHS students, 2) How general patterns of scaffolding of the CTA are possible to be developed, and 3) How part of examples of student worksheet in which the scaffolding stages appear in Physics learning with CTA.

\section{THEORETICAL FRAMEWORK}

Related to the question above, literature review focuses on two topics. Those are pattern of Scaffolding on Causalitic-thinking Approach (CTA) and Problem-solving Ability (PSA).

\section{THE CAUSALISTIC-THINKING APPROACH}

Approach is a way to do something. In this paper, it is means that an approach is point of view of learning process. With respect to which is more active in learning between student and teacher, this approach is divided into two orientations, student and teacher. The former, in learning, a teacher tends facilitate students to explore information by themselves. While, the latter, in learning, a teacher becomes the source of information, so he actively transfers the information to students.

Causalitic means causality and analytic, so causalitic-thinking is synonymous with causality and analytic thinking. Paul (2003) divides thinking into eight elements including generating objective, proposing question, applying information, needing concept, making conclusion, making assumption, generating understanding, and realizing a point of view, while Gopnik (2007) mentions philosophy approach of causation theory that is named difference-making. This theory agrees that every cause creates a different effect. The cause has to result in or at least modifies possibility for effect to occur. Lenzen (1954) introduces two views of causality concept. First view is that two events are in a series, while the second one is that two events occur in the same time. Furthermore, he mentions two principles of causality. Firstly, causality is reproducible in a space and time. This principle agrees that causes are independent from space and time in resulting effect. Secondly, the 
same initial conditions will result in the same phenomenon series. Besides, Hill (2011) mentions another principle of causality. He agrees that one event (cause) will produce another event (effect) and if the events are separated by space, they have to be separated by time.

Marzano (2008) groups analytical thinking as high order thinking, while, Amer (2005) mentions that the thinking is closely related to creative thinking. He stated that thinking is strongly useful for understanding a phenomenon. Making handful of elements, comparing them, making a rank, selecting the most valuable, and discarding the remaining are the basic idea of this thinking. In causalitic-thinking (CT) view, analytical thinking is defined how far students can identify conditions of causes so they result in determined effect. Kasser (2006) states that identifying needs explanation about facts and/or events in Physics and establishing its explanation has to be presented in terms of fact, concept, principle, theory, and/or law of Physics.

In CT, student has two main activities, causality and analytic thinking. Causality thinking includes understanding phenomenon, determining causes, predicting effects, and differentiating causes that as factors of each effect. While, analytic thinking includes identifying causes that result in effect and codifying explanation that correlate the causes and effect, and establishing an argument why the effects occur. When codifying the explanation, it has to be in terms of fact, concept, principle, theory, and/or law of Physics that is closely related to the causes and/or effect. Thus, analytic thinking is defined as determining and applying fact, concept, principle, theory, and/or law of Physics needed for identifying or compiling all of explanation why the effect occurs.

The CT has elements which are in line with some elements those are mentioned by Paul (2003) and Kasser (2006). Compatibility occurs between the two groups of the elements such as: Understanding in CT agrees with generating objective and generating understanding; determining causes and predicting effects in line with generating objective, proposing question, applying information, and needing concept; while differentiating causes are in line with proposing question and needing concept. Then, compatibility between CT and element identifying from Kasser (2006) includes identifying causes and explaining relation between causes and effect. Thus, elements of CT at least agree with nine among eleven (81\%) elements of thinking from Paul (2003) and Kasser (2006).

\section{THE PROBLEM-SOLVING ABILITY (PSA)}

Problem-solving Ability (PSA) in this paper is deductively defined based on some opinions including Marzano (200) and Marzano (2009). Marzano (2009) states that students need to use knowledge to generate and stanch opinion. While, Marzano (2008) proposes seven focuses of question to encourage Problem-solving including objective, obstacle, the way to handle obstacle, and determining best solution. The last three focuses are the real event, the congeniality between result and solution, and/or the way to change thought.

Marquardt (2004) proposes two approaches with respect to Problem-solving, analytic and integrative. The former agrees that phenomenon has only one solution. While, the latter agrees that phenomenon has many solutions and recommends develop a multi-effect phenomenon where one or more elements of causes in the phenomenon is (are) as variable. Through this phenomenon, students are facilitated to identify conditions of all causes and determine all of possible effects. 
According to two paragraphs above, PSA is defined in two abilities, i.e. ability in using knowledge to select and/or predict all effects when solve phenomenon and ability in identifying how causes result in each effect.

In general, PSA is defined as ability to solve a problem but with respect to causaliticthinking, PSA includes understanding, selecting, differentiating, determining, applying, and identifying (Gopnik, 2007; Rokhmat, 2015; \& Paul, 2003). Understanding means ability to know what idea of a problem, selecting means ability to determine which elements (in problem) as a cause (causes) and effect (effects). In statistics, cause is independent variable and effect is dependent variable. Next, differentiating means ability to differentiate which cause (causes) as factors of effect, while, determining means ability to establish concept, principle, theory, and/or law of Physics that are related to each effect. The other two, applying means ability to apply the concept, principle, theory, and/or law of Physics for explaining why each effect occurs, and finally, identifying means ability to identify conditions of cause (causes) so it (they) results in the effect.

The compatibility CT and PSA: Analyzing phenomenon into its elements, causes and effects, needs understanding of idea and objective of the phenomenon that are in line with consideration and ability to analyze their differences. The needs, understanding, consideration, and ability are closely related to analytic thinking. So, analytic thinking indicates significant role on causality thinking. This fact is supported by Paul (2003), Amer (2005), Zschunke (2000), Cohen (2000), and Hamilton (2001).

Three indicators of PSA, understanding, selecting, and differentiating, also and interpretation of Problem-solving are summarized from indicators of analytic thinking from Amer (2005), Zschunke (2000), Cohen (2000), Parselle (n.d.), and Hamilton (2001). While, the fourth and fifth indicators (determining and applying) support ability to identify causes (the sixth).

The descriptions above indicate that ability of causality and analytic thinking support PSA. Causality thinking supports ability to select and/or predict effects in phenomenon, while, analytic thinking supports ability to identify how causes result in determined effect. So, causality and analytic thinking support the PSA.

\section{THE SCAFFOLDING PATTERNS IN CAUSALITIC-THINKING APPROACH}

Patterns of scaffolding: Pattern of scaffolding is defined as specific form of worksheet aimed to give assistance stages in facilitating students to solve a phenomenon. The worksheet of CTA consists of three main elements, blanks of causes, effects, and arguments which relate the causes and effects. Joyce (2011) defines scaffolding as any way to optimize meta-cognitive control of student in learning. This meta-cognitive, in learning, is related to executive control of students so they realize how to learn, develop instruments, and they also develop their critical thinking.

In this paper, scaffolding pattern means how the elements are prepared. In standard pattern, the elements of worksheet are let empty. However, in scaffolding, there is one or more assistance stages, so students have more possibilities to solve phenomenon. The example of the preparation such as the number of one or more elements (causes and/or effects) is informed or part of the causes, effects, and/or arguments is informed. 


\section{METHOD}

This three year research used mixed method of embedded experimental design that consists of two phase approach. This method put the main approach of qualitative and quantitative was embedded in. This research consisted of four main activities, those were analyze subject matter, design instruments, validate instruments (expert and empiric), and the last analyze and interpret of the instruments (Crewell, 2007).

Qualitative data were found in analyzing subject, developing instruments, and in expert validating, also in analyzing and interpreting results of this research. Quantitative data were found from pre-test and post-test. The tests were held in process of empirical instrument validation. Qualitative approach was applied to analyze data through filling attitude scale, observation, and of interviews. These data were especially about CTA, scaffolding patterns, and their characteristics. While, quantitative approach was used to analyze the results (increase) of PSA. Finally, information about their superiority and restrictiveness of the scaffolding patterns of the CTA, also the PSA increase were used to make recommendations to develop better instruments and its implementation.

The subjects of this research were second year Students of Senior High School (SHS) in Mataram Indonesia of year 2016/2017. The subjects included two classes, control (22 females and 11 males) and experiment (17 females and 15 males). In empirical validation, CTA was implemented in the experiment. To validate instruments of the CTA qualitatively, information from all students was gathered. Total score of the six abilities on both control and experiment classes were tested by using ANAVA two factor design (Minium, 1993). This test was aimed to investigate the impact the CTA in scaffolding pattern to PSA with respect to student's gender and their Junior High School (JHS) origin.

\section{RESULT}

\section{The Problem Solving Ability (PSA)}

The problem solving ability (PSA) is obtained from post-test on both control and experiment classes. Meanwhile, the score of the PSA is counted from the average of all its indicator (IPSA) scores, including scores of understanding (IPSA-1), selecting (IPSA-2), differentiating (IPSA-3), determining (IPSA-4), applying (IPSA-5), and identifying (IPSA6). The scores include main PSA and its interaction. The former consists of scores for control and experiment classes, male and female students, and those, students having original JHS, Sekolah Menengah Pertama (SMP) and non-SMP. SMP means general government JHS while non-SMP means other JHS including private JHS and JHS that has dual main orientation of study, general and religion. The latter, consists of interaction between implementation of scaffolding CTA and gender and between the implementation and original JHS of students. Its impact significance was determined by values of $F_{\text {counted }}$ (calculated from ANAVA test) and $F_{\text {table }}$ (with significance level 5\%). We reject the null hypothesis if the $F_{\text {counted }}$ greater than $F_{\text {table }}$ (Minium, 1993).

To simplify the explanation, the average of PSA on each IPSA and the results of ANAVA test above are presented in tables. The presentations include average score of IPSA (Table 1), PSA (Table 2) and lists output of the tests that are related to gender (Table 3) and origin of JHS (Table 4). 
Table 1 Average Score of the Indicator of Problem-solving Ability (IPSA) Related to Gender and Origin of JHS on the Control and Experiment Classes

\begin{tabular}{lcccccc}
\hline \multirow{2}{*}{ Data Attributte } & \multicolumn{7}{c}{ Indicators of Problem Solving Ability (IPSA) } \\
\cline { 2 - 7 } & IPSA-1 & IPSA-2 & IPSA-3 & IPSA-4 & IPSA-5 & IPSA-6 \\
\hline Male & 100 & 73 & 30 & 7 & 25 & 36 \\
\hline Female & 100 & 65 & 32 & 18 & 24 & 38 \\
\hline SMP & 100 & 50 & 35 & 18 & 25 & 25 \\
\hline non-SMP & 100 & 75 & 29 & 13 & 24 & 42 \\
\hline & \multicolumn{7}{c}{ Control Class } \\
\hline Male & 100 & 92 & 28 & 55 & 43 & 67 \\
\hline Female & 100 & 88 & 22 & 13 & 31 & 47 \\
\hline SMP & 100 & 85 & 32 & 25 & 33 & 50 \\
\hline non-SMP & 100 & 94 & 19 & 40 & 40 & 62 \\
\hline
\end{tabular}

Table 2 Average Score of Problem-solving Ability Related to Gender and Origin of JHS

\begin{tabular}{|c|c|c|c|c|c|c|c|c|c|}
\hline \multirow[b]{2}{*}{ Groups } & \multirow{2}{*}{$\begin{array}{c}\text { Control } \\
\text { Class }\end{array}$} & \multirow{2}{*}{$\begin{array}{l}\text { Experiment } \\
\text { Class }\end{array}$} & \multirow[b]{2}{*}{ Male } & \multirow[b]{2}{*}{ Female } & \multicolumn{2}{|c|}{ Control Class } & \multicolumn{2}{|c|}{ Experiment Class } & \multirow{2}{*}{$\begin{array}{c}\text { All } \\
\text { Classes }\end{array}$} \\
\hline & & & & & Male & Female & Male & Female & \\
\hline \multirow{3}{*}{$\begin{array}{c}\text { Average } \\
\text { Score }\end{array}$} & \multirow{3}{*}{45.71} & \multirow{3}{*}{56.77} & 56.09 & 47.86 & 45.08 & 46.02 & 64.17 & 50.25 & \multirow{3}{*}{51.15} \\
\hline & & & SMP & non-SMP & SMP & non-SMP & SMP & non-SMP & \\
\hline & & & 49.33 & 52.29 & 42.08 & 47.28 & 54.17 & 59.07 & \\
\hline
\end{tabular}

Table 1 displays the average score of IPSA with respect to gender and origin of JHS students. IPSA-1 reveals perfect attainment that indicates all students understand each phenomenon of the problem they faced. Conversely, for the other five, only IPSA-2 of the students in experiment class that shows high attainment (85 to 94). This indicates that only students in the class that have high ability to select which components of each phenomenon as causes and/or effects. The average scores of all IPSA (IPSA-1 to IPSA-6) of each attribute result in part scores as shown in Table 2.

Table 2 shows the average score of PSA with respect to gender and origin of JHS students. The PSA average score of experiment class (56.77) is higher than that of control class (45.71). Next, in all classes (control and experiment), the PSA average score of male students (56.09) is also higher than that of female students (47.86) but the score of nonSMP students (52.29) is higher than of SMP students (49.33). The PSA average score of all students of both, students of control and experiment classes, is 51.15. In each class, the PSA average scores are as follows: In control class, the score of female students (46.02) is higher than of male students (45.08) as well as of non-SMP students (47.28) than of SMP students (42.28); In experiment class, the score of male students (64.17) is higher than that of female students (50.25) as well as of non-SMP students (59.07) than that of SMP students (54.17).

Table 3 Results of ANAVA Analysis of PSA Related to Gender

\begin{tabular}{lcccc}
\hline & $\begin{array}{c}\text { Raw } \\
\text { (Male- } \\
\text { Female) }\end{array}$ & $\begin{array}{c}\text { Column } \\
\text { (Control- } \\
\text { Experiment) }\end{array}$ & $\begin{array}{c}\text { Interaction } \\
\text { (between raw } \\
\text { and column) }\end{array}$ & $\begin{array}{c}\text { Within } \\
\text { Cell }\end{array}$ \\
\hline Variance & 1055.73 & 1988.64 & -174 & 218.3 \\
\hline Degree of freedom (df) & 1 & 1 & 1 & 61 \\
\hline $\mathrm{F}_{\text {caunted }}$ & 4.835 & 9.108 & -0.798 & \\
\hline $\begin{array}{l}\mathrm{F}_{\text {table }} \text { (significance with level } \\
\text { 5\%, numerator 1, } \\
\text { denominator 61) }\end{array}$ & 4.00 & 4.00 & 4.00 & \\
\hline Significance & $\mathrm{S}$ & $\mathrm{S}$ & $\mathrm{TS}$ & \\
\hline
\end{tabular}


Table 3 shows the lists of variance, degree of freedom (df), values of $F_{\text {counted }}$ and $F_{\text {table, }}$ and its significance resulted from ANAVA analysis of PSA which is related to gender.

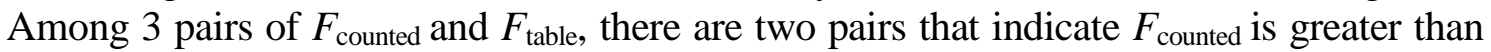
$F_{\text {table }}$ (on raw and column) while on its interaction $F_{\text {counted }}$ is smaller than $F_{\text {table. These facts }}$ mean that PSA between male and female students and between students of control and experiment classes are significantly different. On the other hand, there is no significant difference of PSA between male students of control and experiment classes or between female students of control and experiment classes.

Table 4 Results of ANAVA Analysis of PSA Related to Origin of JHS

\begin{tabular}{lcccc}
\hline & $\begin{array}{c}\text { Raw (SMP- } \\
\text { nonSMP) }\end{array}$ & $\begin{array}{c}\text { Column } \\
\text { (Control- } \\
\text { Experiment) }\end{array}$ & $\begin{array}{c}\text { Interaction } \\
\text { (between raw } \\
\text { and column) }\end{array}$ & $\begin{array}{c}\text { Within } \\
\text { Cell }\end{array}$ \\
\hline Variance & 134.64 & 1988.64 & 5,478 & 237.5 \\
\hline Degree of freedom (df) & 1 & 1 & 1 & 61 \\
\hline $\mathrm{F}_{\text {caunted }}$ & 0.567 & 8.372. & 23.062 & \\
\hline $\begin{array}{l}\mathrm{F}_{\text {table }} \text { (significance with level } \\
\begin{array}{l}\text { 5\%, numerator 1, } \\
\text { denominator 61) }\end{array}\end{array}$ & 4.00 & 4.00 & 4.00 & \\
\hline Significance & $\mathrm{TS}$ & $\mathrm{S}$ & $\mathbf{S}$ & \\
\hline
\end{tabular}

Similarly, Table 4 also shows the lists of variance, degree of freedom (df), values of $F_{\text {counted }}$ and $F_{\text {table, }}$ and its significance resulted from ANAVA analysis of PSA but the outputs are related to original JHS of students. Among 3 pairs of $F_{\text {counted }}$ and $F_{\text {table, there are }}$ also two pairs that indicate $F_{\text {counted }}$ is greater than $F_{\text {table }}$ (on column and interaction) while on raw $F_{\text {counted }}$ is smaller than $F_{\text {table. }}$. These facts mean that PSA between students of control and experiment classes and between students with the origin of JHS of SMP of control and experiment classes or between students with the origin of JHS of non-SMP of control and experiment classes are significantly different. However, there is no significant difference of PSA between students with the origin of JHS of SMP and non-SMP.

\section{The General Patterns of Scaffolding in Learning with CTA}

Scaffolding patterns mean what and/or how far assistance stages are given in a student worksheet in Physics learning with the CTA which is a part of instruments of this research. Each student worksheet has three main parts, i.e. part 1 and 2 respectively is blank of causes and effects. Next, part 3 is space for identifying or arranging arguments.

In this research, at least it has been developed 7 main groups of the scaffolding patterns. The assistances which are given include information number of all causes (group 1), effects (group 2), or both, of all causes and effects (group 3) in phenomenon, some examples of causes (group 4), effects (group 5), causes and effects (group 6). Next, the assistance includes information of example of identifying (group 7). However, the assistances can also be arranged as combination of two or more among the groups. Thus, in accordance with scaffolding CTA, the assistance is possible to be given with respect to parts of causes, effects, and identifying. Note: Form of causality table of each phenomenon at recent time is provided, so the students only need to write in the elements of causes and effects. 


\section{The Example of Student Worksheet in Physics Learning with CTA}

These examples of worksheet were closed with arrangement of phenomenon. In general, a phenomenon is mono effect, that is, it only has one effect or answer. However, in this learning, the phenomenon is multi-effects, that is, has more than one effect or answer. To arrange this type of phenomenon, one or more causes, are designed as variable, that is, have more than one condition or value. Statistically, in this phenomenon, cause means independent variable while effect means dependent variable. The combination of determined condition of each causes will result in only one effect. Designing one or more causes as variable results in more than one combinations of conditions of each causes and so it also results in more than one effect. The number of the effects exactly is the same as the number of combination of conditions of the causes. On the other hand, to limit the number of possible effects, it is possible to confine question on phenomenon such as making specific review.

Since 2013, it has been arranged more than 20 student worksheet in Physics learning with this CTA on some sub-subjects. The sub-subjects include measurements, kinematics, dynamics, Newton's law about movement, work and energy, gravity, linear momentum, thermodynamics, rigid body equilibrium, fluid, optics, and electric. However, this paper will only present one example of them on fluid to limit number of pages. This example is not more than as general reference for lecturer, teacher, or researcher who intends to develop instruments of learning with this approach.

Example:

Phenomenon: Suppose two identical paper sheets are hung so their position is vertical and parallel each other from left to the right namely respectively as paper 1 and 2 . Next, from the top, air is blown downward through each side of the papers. Velocity of air at left side of paper 1 , between paper 1 and 2, and at right side of paper 2 respectively is $v_{1}, v_{12}$, and $v_{3}$ with $v_{1}=v_{12}$ but $v_{3}$ can be smaller, the same, or greater than $v_{12}$. Based on the conditions, what will happen on each paper with respect to their possibility to move? Explain your answer why it happens and apply the related concept, principle, theory, and/or law of Physics in your explanation.

\section{Part of student worksheet:}

Table 5 The Causality Table of this Phenomenon

\begin{tabular}{|c|c|}
\hline Causes (There are 4 causes) & Effects (There are 4 effects) \\
\hline $\begin{array}{l}\text { 1. Two identical paper sheets (paper } 1 \text { and } \\
\text { 2) are hung vertical and parallel (from } \\
\text { left to the right) }\end{array}$ & 1. Paper 1 will not move \\
\hline $\begin{array}{l}\text { 2. Through each side of the paper air from } \\
\text { the top is blown downward }\end{array}$ & 2. Paper 2 will not move \\
\hline $\begin{array}{l}\text { 3. Air velocity on the left side of paper } 1 \\
\left(v_{1}\right) \text { equals to velocity between paper } 1 \\
\text { and } 2\left(v_{12}\right)\end{array}$ & $\begin{array}{l}\text { 3. Paper } 2 \text { will move to the } \\
\text { right }\end{array}$ \\
\hline $\begin{array}{l}\text { 4. Air velocity on the right side of paper } 2 \\
\left(v_{3}\right) \text { can be smaller, the same, or greater } \\
\text { than } v_{12} \text {. }\end{array}$ & $\begin{array}{l}\text { 4. Paper } 2 \text { will move to the } \\
\text { left }\end{array}$ \\
\hline
\end{tabular}


Arguments

Effect 1 : Velocity of air on both sides of paper 1 , left $\left(v_{1}\right)$ and right $\left(v_{12}\right)$ are the same so accordance to the Bernoully law, air pressure on those sides are also the same which results in no force that move the paper.

Effect 2 : This effect occurs only when velocity of air on both the right side of paper $2\left(v_{3}\right)$ is the same as $v_{12}$. Similarly with condition of $v_{1}$ and $v_{12}$ in effect 1 , accordance to the Bernoully law, air pressure on both sides of the paper are also the same and so results in no force that move the paper.

Effect 3 : This effect occurs only when velocity of air on the right side of paper 2 $\left(v_{3}\right)$ is greater than $v_{12}$. With this condition, air pressure on the right side is lower than that on the left side which results in force to the right acting on the paper and causes paper moves to the right. This fact is in line with Bernoully law that in air moving faster will be lower air pressure and conversely in air moving slower will be higher air pressure.

Effect 4 : This effect occurs only when velocity of air on the right side of paper 2 $\left(v_{3}\right)$ is smaller than $v_{12}$. Similarly explanation with effect 3 , in this condition, there is force to the left acting on the paper and causes paper moves to the left. This fact is also in line with Bernoully law that in air moving faster will be lower air pressure and conversely in air moving slower will be higher air pressure.

The example shows a Physics (fluid) phenomenon and its causality table (Table 5) and space for arguments which both have been answered comprehensively so all causes, effects, and their arguments are already given. The phenomenon has four causes and four effects. When a student does all of the tasks written in the phenomenon, the results will be the same as the example above.

In standard form, the table above is blank (only written "causes" and "effects") as well as space for arguments. To change it into scaffolding form, examples of what should be added are: 1) Write number of causes and/or effects, in the example, "There are 4 causes" and "There are 4 effects"; 2) Write one or more, even all (in maximum assistance) of the four causes; 3) Write one or more, even all (in maximum assistance) of the four effects; 4) Write one or more arguments or explanations; the last 5) Give assistances as combination among the four above.

\section{DISCUSSION}

\section{The Modus of Phenomenon in Physics and the Need of Scaffolding CTA}

Generally, what we find in physics phenomenon is problem with convergent causal model, that is, problems with multi-cause and mono-effect because they only have one answer. To increase the ability of creative thinking, it needs to develop problems with more than one answer or multi-effects phenomenon. The sort of these phenomena agree with CTA which almost all of its instruments is multi-effects. However, the CTA in standard form attainment of PSA of pre-service teacher on seven subjects, movements, Newton's law about work and energy, movement, linear momentum, gravity, 
thermodynamics, and rigid body equilibrium, in average still low. That is, only indicator- 1 (understanding) that has final average score 64, the five others its final average score 51 or less $^{10)}$. To increase attainment of the PSA, it is considerable to arrange instrument of the CTA in scaffolding form. With this scaffolding CTA, students are facilitated to do better than the standard one.

\section{The Relation of This Research with Some Previous Research}

The CTA that is in general based on multi-effects phenomenon lineally encourages the development of creative thinking. This thinking is indicated by fluency, flexibility, and/or originality as what when the students solve an open-ended task (Meyer, 2015). Next, Anwar (2012) mentions besides the three effects, the phenomenon in this sort can also encourage elaboration. Fluency indicates how many answers learner has predicted and flexibility shows how high the level of difficulty we have designed. Next, originality is shown from addition answers written by learner and elaboration is indicated from how learners build their ideas. Furthermore, the CTA also has similarity with strategy that has been developed by Escudero (2009). In their research, undergraduate students were facilitated to investigate all knowledge (concepts and theories) which are possible appear on phenomena (solid and hollow body, ball and cylinder, rolling on inclined coarse surface) through writing as many answers as possible.

\section{The Effectiveness of CTA in Physics Learning from View of Gender and Origin of School}

The Effectiveness of CTA in Physics learning is indicated by significance of PSA increase of students, in this research is on fluids, and how attainment of the PSA of students in experiment class, is it higher than that of students in control class.

The Result of this research shows that average of PSA of students in experiment class is higher than that in control class. This fact occurred on all students and on all categories, i.e. on male and female students, also on students with JHS origin SMP and non-SMP (Table 1). While, the difference of the PSA which is significant occurred as follow: (1) between students in control and experiment classes (Table 3 and 4), (2) between male and female students (Table 3), also (3) between students with JHS origin SMP in control class and students with JHS origin non-SMP in control class, and (4) between students with JHS origin SMP in experiment class and students with JHS origin non-SMP in experiment class (Table 3 and 4). Next, to simplify further discussion the significances respectively are named as significance number (1) up to (4). On the other hand, difference of the PSA which is not significant occurred between students with JHS origin SMP and non SMP, also between male students in control class and female students in control class, and the last, between male students in experiment class and female students in experiment class. Similarly, to abbreviate further discussion the insignificances respectively are named as insignificance number (1) up to (3).

The Significance number (1) is in line with Rokhmat (2013, 2015, 2016, and 2017) which through their research have showed that the CTA is effective in increasing PSA. Next, significance number (2) agrees with Piaw (2013) who indicates that male students are more creative than their female counterparts. This fact is reasonable because the CTA closely is based on multi-effect phenomena having more than one 
correct answer. However, insignificance number (1) occurred with argument that the SHS in students study as one school with moderate quality in town and so students of JHS SMP origin are also in general as students of low up to moderate quality. Conversely, students of JHS non-SMP origin in general are students of moderate up to good quality.

Next, from significances number (3) and (4) and from insignificances number (2) and (3) the change placement students of SMP origin or non-SMP from control to experiment classes or in the other way will affect their attainment of PSA. However, this fact is not valid for male or female students.

\section{Restrictiveness of Scaffolding Form of CTA in Physics Learning}

Some limitations of the implementation of learning by using the scaffolding CTA are: (1) One determined level of assistance stage sometimes causes phenomenon become too easy or too difficult for students and (2) the instruments of scaffolding CTA, especially regarding its phenomenon, usually needs long description, so it causes students indolent to read it comprehensively. The implementation of this learning does not facilitate students to develop their ability to determine what form of causality table which is appropriate with the phenomenon.

\section{How to Reduce the Limitation of Scaffolding CTA in Learning}

It is advisable to follow some stages of preparations. Those are: Prepare in every set of worksheet phenomenon with assistance stages varies from level of high to low, arrange phenomenon with description as short as possible, and if it considered for 100 minutes learning needs only one phenomenon, make it in moderate level of assistance stage. Finally, design learning with group discussion method and set its member of each groups consisting of students from various levels, high, moderate, and low. It is also needed to design learning with this approach in which students have to determine by themselves what form of causality table is suitable with each phenomenon.

\section{CONCLUSION}

The instruments of Physics learning with Causalitik Thinking Approach (CTA) have been developed in scaffolding form which is significantly effective to increase Problem Solving Ability (PSA) of students on fluids. The assistance stages of the scaffolding include adding information as follow: form of causality table, number of causes, number of effects, some example of the causes, some example of the effects, and some example of explanations about what conditions of the causes so they result in a determined effect. The PSA consists of abilities to understand problem, select causes and effects, differentiate causes which is related to each effect, determine the appropriate concept, principle, theory, and/or law of Physics, apply the concept, principle, theory, and/or law of Physics for identifying causes, and identify conditions of all causes so they result in each effect. It is recommended that lectures and teachers refer to the seven groups of main scaffolding patterns when developing instrument in learning with causalitic approach in scaffolding form. Next, it is also recommended that other researchers to refer the scaffolding patterns when developing instrument in similar learning with respect to investigation of their further implementation. However, to increase the effectiveness of its instruments, it 
remains need some perfection actions of perfecting which include perfecting its design and strategy for implementing.

\section{ACKNOWLEDGMENTS}

We gratefully acknowledge Allah SWT, to staff leader of ministry of research, technology, and High Education of Indonesia, also research institution and all staff leader of Mataram University. We also appreciate all of help given by our colleagues and students of Physics education, Faridatul Hemi, who has joined with our research program. We also acknowledge our family who has supported us in finishing this research and all students of Senior High School who have participated in this research.

\section{REFERENCES}

Amer, A., (2005). Analytical Thinking. Cairo: Center of Advancement of Postgraduate Studies and Research in Engineering Sciences, Cairo University (CAPSCU), 1-14.

Anwar, M., N., Aness, M., Kizar, A., Naseer, M., and Muhammad, G. (2012). "Relationship of Creative Thinking with the Academic Achievements of Secondary School Students". International Interdisciplinary Journal of Education, 1(3), 44.

Baser, M. (2006). "Fostering Conceptual Change by Cognitive Conflict Based Instruction on Students' Understanding of Heat and Temperature Concepts”. Eurasia Journal of Mathematics, Science and Technology Education, 2 (2), July, 96-108.

Cohen, G., A. (2000). Karl Marx’s Theory of History. US: Princeton University Press; OK: Oxford University Press, vii.

Creswell, J. W. \& Clark, V. L. P. (2007). Mixed Methods Research. Thousand Oaks, CA: Sage Publications Inc., 67-71.

Dori, Y. J. \& Belcher, J. (2004). “Improving Students' Understanding of Electromagnetism through Visualizations-A Large Scale Study". The National Association for Research in Science Teaching Conference (NARST).

Dykstra, D. I.,\& Sweet, D. R. (2009). “Conceptual Development about Motion and Force in Elementary and Middle School Students”. American Association of Physics Teachers, Am. J. Phys., 77 (5), May, 468-476.

Escudero, C., Moreira, A. M., \& Caballero, C. (2009). “A Research on Undergraduate Students' Conceptualizations of Physics Notions Related to Non-sliding Rotational Motion”. Lat. Am. I Phys. Educ., 3 (1), January, 1-7.

Gopnik, A. \& Schulz, L. (2007). Causal Learning; Psychology, Philosophy, and Computation. New York: Oxford University Press Inc., 86-94.

Hake, R. (2007). "Six Lessons from the Physics Education Reform Effort”. Latin American Journal of Physics Education, 1(1), September, 24-27.

Hamilton, A. (2001). Managing Subjects for Success. London: Albert Hamilton and Thomas Telford Limited, 36-44.

Hill, S. E. (2011). "Reanalysing the Ampere-Maxwell Law”. AAPT Physics Education, The Physics Teacher, 49, September, 343-345.Redlands, CA: University of Redlands.

Hung, W. \& Jonassen, D. H., (2006). “Conceptual Understanding \& Causal Reasoning in Physics”. International Journal of Science Education, 28 (13), October, 1601-1621.

Joyce, B., Weil, M., Calhoun, E. (2011). Models of Teaching, Model-model Pengajaran, Edisi Kedelapan. Yogyakarta: Pustaka Pelajar.

Kasser J. L., (2006). ). Philosophy of Science, part 2 of 3. USA: The Theaching Company, 92-126. 
Lenzen, V. F. (1954). Causality in Natural Science. Springfield, IL: Charles C Thomas Publisher, 2-27.

Marquardt, M. J. (2004). Optimizing the Power of Action Learning: Solving Problems and Building Leaders in Real Time. Mountain View, CA: Davies-Black Publishing, 91-103.

Marzano, R. J. \& Kendall, J. S. (2008). Designing \& Assessing Educational Objectives: Applying the New Taxonomy. Thousand, CA: Corwin Press, 3.

Marzano, R. J. \& Brown, J. L. (2009). A Handbook for the Art and Science of Teaching. Alexandria, VA: ASCD, 134-135.

Meder, B. (2006). Seeing versus Doing: Causal Bayes Nets as Psychological Models of Causal Reasoning, Dissertation, zur Erlangung des Doktorgrades der MathematischNaturwisshensclaftlichen Fakultaten- Universitat zur Gottingen, 31.

Meyer, A. A., and Lederman, N. G. (2015). “Creative Cognition on Secondary Science: An exploration of divergent thinking in science among adolescents”.International Journal of Science Education. Retrieved from: http://dx.doi.org/10.1080/09500693.2015.1043599.

Minium, E. W., King, B. M., \&Bear, G. (1993). Statistical Reasoning in Psychology and Education. New York, NY: John Wiley \& Sons, Inc., 488-489, 579.

Obaidat, I. \& Malkawi, E. (2009). "The Grasp of Physics Concepts of Motion: Identifying Particular Patterns in Students' Thinking”. International Journal for the Scholarship of Teaching and Learning, 3 (1), January, 11-12.

Parselle, C. (n.d.). Analytical/Intuitive Thinking. Google, http://EzineArticle.com/expert/ Charles_Parselle/8291.

Paul, R. \& Elder, L. (2003). The Foundations of Analytic Thinking: The Elements of Thinkingand The Standards They Must Meet, Second edition. Retrieved from:www.criticalthinking.org, 3-15, 42. [Accessed 11 August 2011].

Piaw, C., Y. (2013). "Relationship between thinking styles and ability to pay attention of Malaysian male and female student teachers.” Procedia - Social and Behavioral Sciences 116 (2014) 4839 - 4843: Available online at www.sciencedirect.com.

Rasagama, I. G. (2011). Pengembangan Program Perkuliahan Fisika untuk Meningkatkan Kemampuan Menganalisis dan Mengkreasi Mahasiswa Teknik Konversi Energi Politeknik [The Development of Physics Lecturing Programme to Increase Ability to Analise and Create for Students of Energy Conversion Technical of Polytechnic]. Disertasi Doktor pada Pendidikan IPA. Universitas Pendidikan Indonesia: tidak diterbitkan.

Rokhmat, J. (2013). Peningkatan Kemampuan Pemecahan Masalah Mahasiswa Calon Guru Fisika melalui Berpikir Kausalitas dan Analitik [The Increase of Problem-solving Ability of Physics Pre-service Student through Causality and Analytic Thinking]. Disertasi Doktor pada Pendidikan IPA. Universitas Pendidikan Indonesia: tidak diterbitkan.

Rokhmat, J. (2015). Pengembangan Model Pembelajaran Berbasis Proses Berpikir Kausalitas dan Analisik untuk Meningkatkan Kemampuan Pemecahan Masalah Mahasiswa Calon Guru [The Development of Learning-model Based on Causality and Analytic Thinking to Increase Problemsolving Ability of Pre-service Teacher]. Penelitian Strategis Nasional. Universitas Mataram: tidak diterbitkan.

Rokhmat, J., Marzuki, Hikmawati, and Verawati, N. N. S. P. (2017). "Instrument Development of Causalitic Thinking Approach in Physics Learning to Increase Problem Solving Ability of Preservice Teacher.” American Institute of Physics Conference Proceeding, 03000-3 - 03000-5.

Yürük, N. (2007). “A Case Study of One Student’s Metaconceptual Processes and the Changes in Her Alternative Conceptions of Force and Motion”. Eurasia Journal of Mathematics, Science \& Technology Education, 3 (4), 305-325. Turkey: Gazi Universitesi.

Zschunke, A. (2000). Reference Materials in Analytical Chemistry. Berlin, Germany: Springer Verlag Berlin Heidelberg, 2. 
